\title{
Phytochemical Screening and Free Radical Scavenging Potential of Maha Vallathy Leghiyam Aqueous Extract
}

\author{
Priyanka G ${ }^{1,2}$, Chandrasekhar $M^{1}$, Kayalvizhi $E^{\mathbf{1}}$, Chinmayi Sri Amulya $\mathbf{Y}^{\mathbf{3}}$ \\ ${ }^{1}$ Meenakshi Medical College Hospital and Research Institute, Kanchipuram, Tamil Nadu, India. \\ ${ }^{2}$ Ragas Dental College and Hospital, Uthandi, Chennai, Tamil Nadu, India. \\ ${ }^{3}$ Cancer Biology lab, Molecular and Nanomedicine Research unit, Sathyabama Institute of Science and \\ Technology, Chennai,Tamil Nadu, India.
}

\begin{abstract}
Correspondence Author: Dr. Chandrasekhar Madhavan
Vice Principal and HOD, Meenakshi Medical College Hospital \& Research Institute, Kanchipuram, Tamil Nadu, India
\end{abstract}

\begin{abstract}
Phytochemicals such as alkaloids, flavonoids, pigments, phenolics, terpenoids, steroids and essential oils are a large group of plant-derived compounds commonly found in diets high in fruits, vegetables, beans and cereals. The sample of Maha Vallathy Leghiyam (MVL) was analyzed for their phytochemical compositions, vitamins and minerals constituents. Based on the observed results explored the presence of bioactive constituents comprising flavonoids, phenols. These substances are the main reason for beneficial role against human health related problems, and it is responsible for the anti-inflammatory, antioxidant, antimicrobial, antitumor and anticancer properties. During the present study, we have tested the Antioxidant activity of through DPPH scavenging assay. The phytochemical screening revealed the extract richness in Tannins, Phlobatannin, Saponins, Flavonoids, Steroids and Alkaloids. Antioxidant activity was determined by DPPH radical scavenging assay, in which $\mathrm{IC}_{50}$ values obtained by $\mathrm{DPPH}$ activity for MVL aqueous crude extract was found to be $50 \mu \mathrm{g} / \mathrm{mL}$. The obtained results suggest that MVL has promising antioxidant activity and could serve as potential source of natural antioxidants.
\end{abstract}

Keywords: Phytochemical; metabolites; alkaloids; minerals; antimicrobial property; MVL

\section{Introduction}

Phytochemicals are the plant chemicals obtained from various fruits, vegetables, nuts, pulses etc., which have been proved to reduce the risk of many chronic diseases ${ }^{1-3}$. These phytochemicals are classified into phenolics, terpenoids and steroids, alkaloids and other chemicals ${ }^{4,5}$. These are extensively used as antioxidants, anti-cancerous $^{6}$, cytotoxicants, anti-microbials, detoxifying agents, anti-rheumatics, anti-malarial, hepaticidal ${ }^{78,9}$ etc. The discovery of antibiotics from plants has brought about a revolution in the medicine world as they are being used for treating various bacterial diseases ${ }^{10,11}$. As the microbes grew resistant to many of the existing antimicrobials, various plant derivatives have been reported for their studies involving active phytochemicals and bioactive compounds because of their replenished antibacterial activity. Due to the presence of synergistic effect, a plants crude extract is more liable for eliminating the microbes than the isolated components of the plant ${ }^{12-15}$. 
Priyanka G ${ }^{1}$, International Journal of Ayurvedic \& Herbal Medicine 9(3) May.-June. 2019 (3484-3491)

MahaVallathyLeghiyam (MVL), is one such phytochemical which is a crude mixture of plant extract. It is to be specific, a siddha herbal medicine which has an approximate of around 30-40 ingredients of biological importance $^{16}$. It has been, in previous reports, prescribed as a drug for various ailments including as an antiAIDS drug ${ }^{17}$. Many reports have demonstrated TLC and HPTLC studies of MVL proving its medical importance as an herbal drug. Also various drugs and its components are identified within herbal plants that are effective antibiotics (Basile et al., 2000) ${ }^{18}$. This study focuses on the anti-bacterial activity of MVL based on its constituents of phytochemical, vitamin, mineral and several other bioactive compounds concentrations. Since, medieval times Since, medieval times MVL has been in practice and prescribed for various ailments but its prognostic study over oral cancer is mere. Instead of surgical removal, chemotherapeutics and radiotherapy as a routine modality of treating this type of cancer, natural therapies can be a good substitute. Even this handmade preparation of MVL is rich in phytochemicals and antioxidants which can act a natural chemo preventant to inhibit oxidation associated free radicals.

\title{
MATERIALS AND METHODS
}

\section{Flavonoids}

From the given sample $2 \mathrm{~mL}$ of extract was taken and mixed with few drops of $20 \% \mathrm{NaOH}$. Formation of intense yellow color was observed. To that yellow color mixture few drops of $70 \%$ diluted HCL was added. The disappearance of yellow color was observed. The formation and disappearance of yellow color indicate the presence of flavonoids.

\begin{abstract}
Alkaloids
$10 \mathrm{ml}$ of extract was taken from the given sample. In that, $8 \mathrm{~mL}$ Picric acid was added. The formation of orange color was observed. And then the appearance of dark orange or purple color was observed. These color changes indicate the presence of alkaloids.
\end{abstract}

\section{Saponins}

From the given sample $2 \mathrm{ml}$ extract was taken and $5 \mathrm{ml}$ of distilled water was added, which is need to be vigorously shaken. The formation of bubbles and persistent form foam indicates the presence of saponins.

\section{Tannin}

$2 \mathrm{~mL}$ of extract was taken. In that $10 \%$ of alcoholic Ferric Chloride was added. The formation of brownish blue or black color was observed. The color change indicates the presence of tannin.

\section{Phenolic Compound}

$2 \mathrm{ml}$ of extract was taken. In that $2 \mathrm{ml}$ of $5 \%$ Ferric Chloride was added. The formation of Blue color was observed. This indicates the presence of phenolic compound.

\section{Terpenoids}

From that given sample $1 \mathrm{ml}$ of extract was taken. In that $0.5 \mathrm{ml}$ chloroform followed by few drops of con. $\mathrm{H}_{2} \mathrm{SO}_{4}$ was added. The formation of reddish-brown color was observed. This indicates the presence of terpenoids.

\section{Glycosides}

$1 \mathrm{~mL}$ of given sample was taken. In that $0.5 \mathrm{ml}$ of glacial acetic acid and $1 \%$ aqueous Ferric Chloride were added. The formation of brownish ring was observed. This indicates the presence of glycosides.

\section{Calcium ions}

Add 10 drops of sample and few drops of aqueous Ammonia solution, followed by few drops of $1 \mathrm{M}$ Ammonium Oxalate. The formation of white precipitate indicates the presence. 
Priyanka G ${ }^{1}$, International Journal of Ayurvedic \& Herbal Medicine 9(3) May.-June. 2019 (3484-3491)

\section{Sulphate ions}

Add 10 drops of sample, few drops of dilute $\mathrm{HCl}$ and again few drops of $1 \mathrm{M}$ barium chloride. Appearance of white precipitate indicates presence of Sulphate ions.

\section{Carbonate}

Add 10 drops of sample, few drops of concentrated $\mathrm{HCl}$. Evolution of $\mathrm{CO}_{2}$ indicates the presence of carbonate.

\section{Starch}

To 10 drops of sample, add few drops of $1 \mathrm{M}$ Iodine solution. Formation of blue black color indicates the presence of starch.

\section{Reducing sugar}

To $3 \mathrm{~mL}$ drops of sample add Fehling's solution and Fehling's solution B. Kept in water bath for $15 \mathrm{~min}$. The formation of green suspension and red precipitate indicates the presence of reducing sugar.

\section{Amino acid}

Add $1 \mathrm{~mL}$ of sample, 2or 3 drops of $0.5 \%$ Ninhydrin reagent. Kept in water bath for few min. Formation of purple/blue colour indicates the presence of amino acids.

\section{Ferrous ion}

Add 10ml of sample, few drops of $0.5 \mathrm{M}$ Potassium Thiocyanate. Formation of deep red solution indicates the presence of ferrous ion.

\section{Halides}

To few drops of sample, add dilute Nitric acid and few drops of Silver Nitrate.

Formation of white precipitate indicates for chloride

Formation of cream precipitate indicates for bromide

Formation of yellow precipitate indicates for iodide

\section{Phosphate}

To few drops of sample add few drops 1M of Ammonium Molybdate. Formation of deep yellow color indicates presence of phosphate.

\section{Sterols}

To $2 \mathrm{ml}$ of solution, add $2 \mathrm{ml}$ of Chloroform, $2 \mathrm{ml}$ of concentrated Sulphuric acid. Chloroform layer appears red and acid layer shows fluorescence.

\section{In vitro Antioxidant activity}

\section{Diphenyl-2-picrylhydrazyl (DPPH) radical scavenging assay}

The DPPH radical scavenging method was used to evaluate the antioxidant property of the sample. The antioxidant activity was compared with that of the natural antioxidant, ascorbic acid. The concentrations of the MVL extracts required to scavenge DPPH showed a dose dependent response. The antioxidant activity of each sample was expressed in terms of IC50, and was calculated from the graph after plotting inhibition percentage against extract concentration DPPH assay was carried out after making some modifications in the standard protocol (28376770). $1.5 \mathrm{~mL}$ of $0.1 \mathrm{mM}$ DPPH solution was mixed with 1.5 $\mathrm{mL}$ of various concentrations $(10$ to $500 \mu \mathrm{g} / \mathrm{mL})$ of leaf extract. The mixture was shaken vigorously and incubated at room temperature for $30 \mathrm{~min}$ in the dark. The reduction of the DPPH free radical was measured by reading the absorbance at $517 \mathrm{~nm}$ by a spectrophotometer. The solution without any extract and with DPPH and methanol was used as control. The experiment was replicated in three independent assays. 
Priyanka G ${ }^{1}$, International Journal of Ayurvedic \& Herbal Medicine 9(3) May.-June. 2019 (3484-3491)

Ascorbic acid was used as positive controls. Inhibition of DPPH free radical in percentage was calculated by the formula: Inhibition $(\%)=[($ A control-A test $) / A$ control $] \times 100$

Where a control is the absorbance of the control (L-Ascorbic acid) and A test is the absorbance of reaction mixture samples (in the presence of sample). All tests were run in triplicates $(n=3)$, and average values were calculated.

\section{RESULTS}

\section{Qualitative analysis of the Maha Vallathy Leghiyam (MVL)}

The result of the preliminary phytochemical screening was carried out on the Maha Vallathy Leghiyam extracts of all the samples and revealed the presence of a wide range of phytoconstituents including alkaloids, glycosides, saponins, flavonoids, tannins, steroids supporting the reason for its wide range of biological activities as showed in table 1. Tannins, Phlobatannins, Saponins, Flavonoids, Steroids and alkaloids were found to be universally present in crude extract of MVL.

Table 1. Qualitative analysis of the MVL

\begin{tabular}{|c|c|c|c|c|c|c|c|c|c|c|}
\hline $\begin{array}{c}\text { Flavonoi } \\
\mathrm{ds}\end{array}$ & $\begin{array}{c}\text { Alkaloi } \\
\mathrm{ds}\end{array}$ & $\begin{array}{c}\text { Saponi } \\
\mathrm{ns}\end{array}$ & $\begin{array}{c}\text { Tannin } \\
\mathrm{s}\end{array}$ & $\begin{array}{c}\text { Phenolic } \\
\text { compoun } \\
\mathrm{ds}\end{array}$ & $\begin{array}{c}\text { Terpeoi } \\
\mathrm{ds}\end{array}$ & $\begin{array}{c}\text { Glycosid } \\
\mathrm{es}\end{array}$ & $\begin{array}{c}\text { Sterol } \\
\mathrm{s}\end{array}$ & $\begin{array}{c}\text { Carbona } \\
\text { te ion }\end{array}$ & $\begin{array}{c}\text { Reducin } \\
\mathrm{g} \text { sugar }\end{array}$ & $\begin{array}{c}\text { Starc } \\
\mathrm{h}\end{array}$ \\
\hline++ & - & - & + & + & + & + & + & - & + & + \\
\hline
\end{tabular}
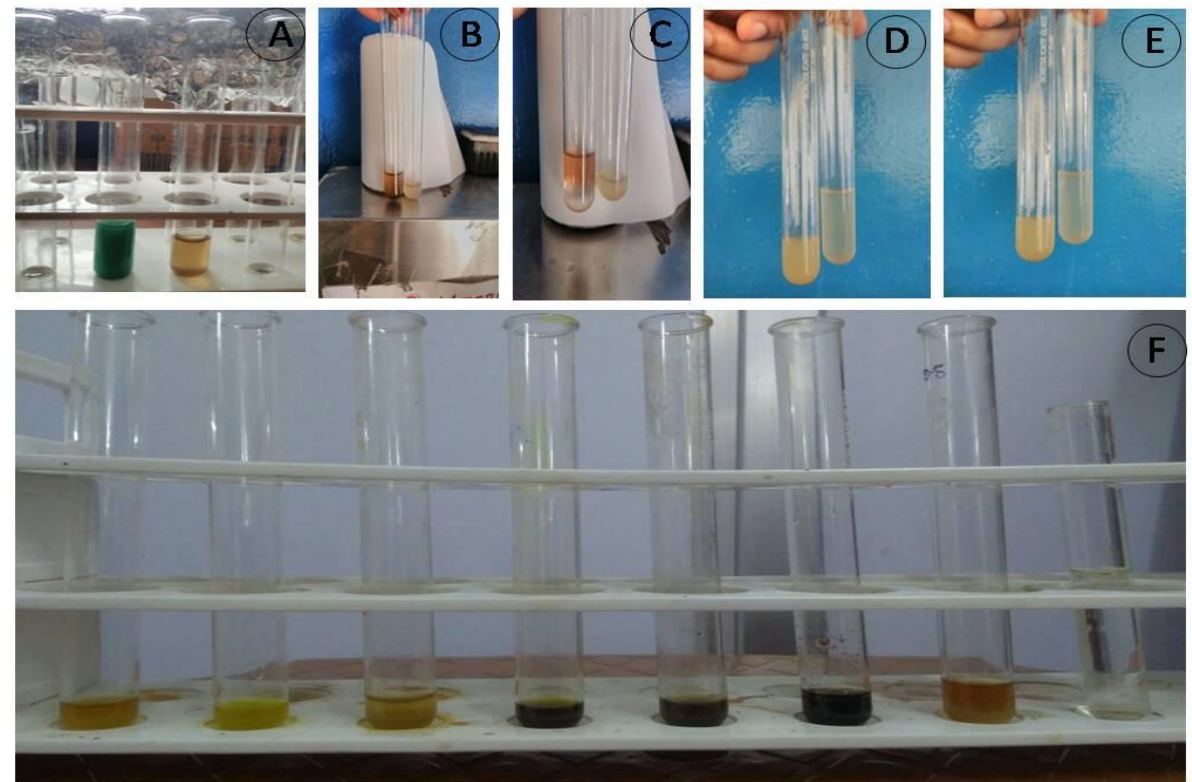

Figure 1: A -flavanoids and alkaloids, B-saponins, C-tannins, D-phenols, E-terpenoids, F-glycosides

Table 2: Solubility Analysis of MVL

\begin{tabular}{|l|c|c|c|c|c|c|c|c|c|}
\hline Solvents & Hexane & Toluene & Chloroform & $\begin{array}{c}\text { Ethyl } \\
\text { acetate }\end{array}$ & Acetone & Ethanol & Methanol & Water & DMSO \\
\hline Lehiyam & + & - & ++ & - & - & ++ & +++ & +++ & +++ \\
\hline
\end{tabular}

+++ Completely Soluble, ++ Moderately Soluble, + Barely Soluble with small particles, - indicates completely insoluble.

\section{Qualitative analysis of MVL}

FLAVONOIDS:

From the given sample $2 \mathrm{ml}$ of extract was taken and mixed with few drops of $20 \% \mathrm{NAOH}$. Formation of 
Priyanka G ${ }^{1}$, International Journal of Ayurvedic \& Herbal Medicine 9(3) May.-June. 2019 (3484-3491)

intense yellow color was observed. To that yellow color mixture few drops of 70\% diluted HCL was added. The disappearance of yellow color was observed. The formation and disappearance of yellow color indicate the presence of flavonoids.

\section{ALKALOIDS:}

$10 \mathrm{~mL}$ of extract was taken from the given sample. In that, $8 \mathrm{~mL}$ Picric acid was added. The formation of orange color was observed. And then the appearance of dark orange or purple color was observed. This color change indicates the presence of alkaloids.

\section{SAPONINS:}

From the given sample $2 \mathrm{~mL}$ extract was taken and $5 \mathrm{ml}$ of distilled water was added, which is need to be vigorously shaken. The formation of bubbles and persistent form foam indicates the presence of saponins.

\section{TANNIN:}

$2 \mathrm{~mL}$ of extract was taken. In that $10 \%$ of Alcoholic Ferric Chloride was added. The formation of brownish blue or black color was observed. The color change indicates the presence of tannin.

\section{PHENOLIC COMPOUND:}

$2 \mathrm{~mL}$ of extract was taken. In that $2 \mathrm{~mL}$ of $5 \%$ Ferric Chloride was added. The formation of Blue color was observed. This indicates the presence of phenolic compound.

\section{TERPENOIDS:}

From that given sample $1 \mathrm{~mL}$ of extract was taken. In that $0.5 \mathrm{ml}$ chloroform followed by few drops of concentrated $\mathrm{H}_{2} \mathrm{SO}_{4}$ was added. The formation of reddish-brown color was observed. This indicates the presence of terpenoids.

\section{GLYCOSIDES:}

$1 \mathrm{~mL}$ of given sample was taken. In that $0.5 \mathrm{~mL}$ of glacial acetic acid and $1 \%$ aqueous ferric chloride was added. The formation of brownish ring was observed. This indicates the presence of glycosides.

\section{STEROIDS:}

$2 \mathrm{~mL}$ of given sample was taken. In that $2 \mathrm{~mL}$ of Chloroform and $2 \mathrm{~mL}$ Sulphuric acid was added. The formation of red color was observed in chloroform layer and fluorescence was observed in the acid layer

Table 3: Qualitative Analysis of the Compound in terms of Solubility

\begin{tabular}{|c|c|c|c|c|c|c|c|c|}
\hline Sample & Flavonoids & $\begin{array}{c}\text { Alkalo } \\
\text { ids }\end{array}$ & $\begin{array}{c}\text { Sapon } \\
\text { ins }\end{array}$ & $\begin{array}{c}\text { Tann } \\
\text { in }\end{array}$ & $\begin{array}{c}\text { Phenolic } \\
\text { compound }\end{array}$ & Terpenoid & Glycosides & Steroid \\
\hline I. Methanol & ++ & + & + & - & - & - & - & + \\
\hline II. Ethanol & - & - & ++ & - & - & - & - & - \\
\hline $\begin{array}{c}\text { III. } \\
\text { Chloroform }\end{array}$ & - & + & + & - & - & - & - & - \\
\hline IV. Hexane & - & - & - & - & - & - & - & - \\
\hline V. Water & + & - & - & + & + & + & + & + \\
\hline VI. DMSO & + & + & - & + & + & + & + & - \\
\hline
\end{tabular}

+++ present in high concentration, ++ present in medium concentration, + present in low amount, - indicates absence. 
Priyanka G ${ }^{1}$, International Journal of Ayurvedic \& Herbal Medicine 9(3) May.-June. 2019 (3484-3491)

\section{DPPH Radical Scavenging Activity}

DPPH stable free radical method is an easy, rapid and sensitive way to survey the antioxidant activity of a specific compound or plant extracts. DPPH radical scavenging activities of the MVL extracts depended are the only on plant type but also upon the extraction of various formulations like siddha and medicinal plant extracts. In general, DPPH scavenging activities increased with water solvents of MVL. These phenolic components possess many hydroxyl groups including o-dihydroxy group which have very strong radical scavenging effect and antioxidant power. In the DPPH assay, the antioxidant was able to reduce the stable radical

DPPH to the yellow colored 1, 1-diphenyl-1, 2-picryl hydrazine. The molecule of 1, 1-diphenyl-1, 2-picryl hydrazine is characterized as a stable free radical by virtue of the delocalization of the spare electron over the molecules a whole. The delocalization also gives rise to the deep violet colour, characterized by an absorption band in methanol solution centered at $517 \mathrm{~nm}$. The dose response curve of DPPH radical scavenging activity of crude extracts of plant was observed, when compared with standard ascorbic acid and shown in figure 2. Antioxidant activity in the form of $\mathrm{IC}_{50}$ values of different extracts were calculated and shown in table 3. Highest antioxidant activity was given by MVL extract at the concentration of $50 \mu \mathrm{g} / \mathrm{mL}$ among all the solvents.

Table 4: DPPH Radical Scavenging Activity - Antioxidant effect (\%)

\begin{tabular}{|c|c|c|c|c|c|}
\hline S.NO & SAMPLE $\mu \mathrm{g} / \mathrm{mL}$ & Water & DMSO & ETHANOL & METHANOL \\
\hline 1 & 10 & $38.42 \pm 1.12$ & $3.23 \pm 0.09$ & $13.80 \pm 0.12$ & $0.44 \pm 1.01$ \\
\hline 2 & 50 & $49.51 \pm 0.89$ & $4.24 \pm 0.04$ & $15.06 \pm 0.09$ & $8.22 \pm 1.09$ \\
\hline 3 & 125 & $62.07 \pm 1.01$ & $6.38 \pm 0.01$ & $15.64 \pm 0.14$ & $25.34 \pm 1.11$ \\
\hline 4 & 250 & $75.97 \pm 1.22$ & $10.68 \pm 0.54$ & $17.06 \pm 0.18$ & $10.87 \pm 1.12$ \\
\hline 5 & 500 & $77.15 \pm 1.12$ & $14.01 \pm 0.74$ & $18.02 \pm 0.19$ & $35.78 \pm 1.23$ \\
\hline 6 & 1000 & $81.56 \pm 0.98$ & $19.72 \pm 0.81$ & $24.61 \pm 0.19$ & $40.36 \pm 1.02$ \\
\hline
\end{tabular}

Results shows in vitro antioxidant effect of different solvent mediated MVL extract. In this, aqueous solvent shows efficient antioxidant activity. The $\mathrm{IC}_{50}$ of the MVL has found to be $50 \mu \mathrm{g} / \mathrm{mL}$, which shows $50 \%$ inhibitory effect.

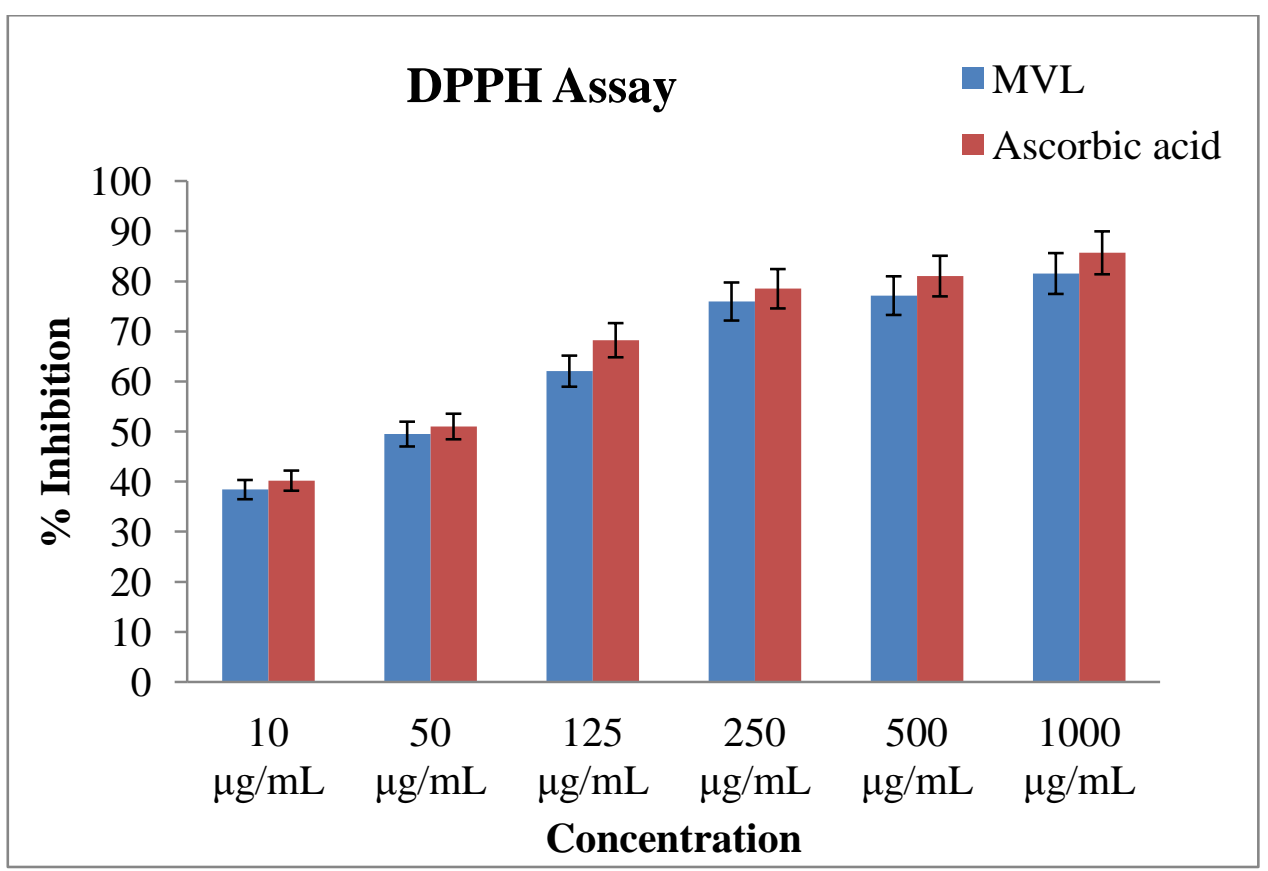

Figure 2: Free radical scavenging activity of MVL compared with standard Ascorbic acid 
Priyanka G ${ }^{1}$, International Journal of Ayurvedic \& Herbal Medicine 9(3) May.-June. 2019 (3484-3491)

\section{DISCUSSION}

Natural compounds of herbal extracts have gained extensive importance due to their effective nature on various ailments. Their biological parameters as clinical products were well reviewed by Prof. (Dr.) CiddiVeeresham in the journal of advanced pharmaceutical technology and research ${ }^{19}$. A detailed explanation of secondary metabolites from natural extracts as a source of potential drug leads was reported by Daniel A Dias ${ }^{20}$. In his review he has reported these herbal extracts to be potential forms of primary and secondary metabolites which gave an insight to carryout this study. In this study, initially when the compound MVL was checked for a qualitative analysis, the traces of flavonoids, tannins, phenolic compounds, terpenoids, glycosides, sterols, reducing sugar and starch. Initially the flavonoids, sterols and tannins were detected by the disappearance of the yellow color by addition of diluted HCl proving MVL has anti-inflammatory activity based on previous report by Kim HP ${ }^{21}$. The traces of phenolic compounds, glycosides and the rest has proven the ability of MVL as an antioxidant and majorly as a potent antibacterial compound based on the studies of Nazeh M, Christina ${ }^{22,23}$. When the solubility test was done for MVL, hexane had minimal solubility while chloroform and ethanol showed moderate solubility and toluene, acetone and ethyl acetate were completely insoluble ${ }^{24}$. Methanol, water and DMSO had the maximum solubility and hence proving high polarity ${ }^{25}$. The DPPH assay showed that at a concentration of 1000 $\mu \mathrm{g} / \mathrm{mL}$, the compound MVL has shown maximum antioxidant ${ }^{26}$ percentage of 81.56 in water as solvent. This was in correlation with the study of Ashafa who has reported an extensive work of antioxidant activity of herbal extracts. Thus, this study concludes that MVL has shown maximum rates of antioxidative, antiinflammative and anti-bacterial nature because of the components present in it.

\section{CONCLUSION}

The finding of this study suggests that this MVL extract could be a potential source of natural antioxidant that could have great importance as therapeutic agents in preventing or slowing the progress of ageing and age associated oxidative stress related degenerative diseases. Further investigation on the isolation and characterization of the antioxidant constituents is however required.

\section{ACKNOWLEDGEMENTS}

The first author is grateful to Dr. A. Madan Kumar, Scientist C, Sathyabama Institute of Science and Technology, Chennai for his constant support and guidance during the study. The authors wish to thank Dr. Savithri Shiva Kumar, Aaranya biosciences Private limited, Research foundation, SIPCOT, Chennai forproviding laboratory facilities to carry out the phytochemical studies.

\section{Conflict of Interest}

The authors declare no conflict of interest.

\section{REFERENCES}

1. Upadhyay S, Dixit M. Role of Polyphenols and Other Phytochemicals on Molecular Signaling. Oxid Med Cell Longev. 2015;2015:504253.

2. Slavin JL, Lloyd B. Health benefits of fruits and vegetables. Adv Nutr. Jul 1 2012;3(4):506-516.

3. Lillehoj H, Liu Y, Calsamiglia S, et al. Phytochemicals as antibiotic alternatives to promote growth and enhance host health. Vet Res. Jul 31 2018;49(1):76.

4. Milugo TK, Omosa LK, Ochanda JO, et al. Antagonistic effect of alkaloids and saponins on bioactivity in the quinine tree (Rauvolfia caffra sond.): further evidence to support biotechnology in traditional medicinal plants. BMC Complement Altern Med. Oct 26 2013;13:285.

5. Mujeeb F, Bajpai P, Pathak N. Phytochemical evaluation, antimicrobial activity, and determination of bioactive components from leaves of Aegle marmelos. Biomed Res Int. 2014;2014:497606. 
Priyanka G ${ }^{1}$, International Journal of Ayurvedic \& Herbal Medicine 9(3) May.-June. 2019 (3484-3491)

6. Talib WH, Mahasneh AM. Antiproliferative activity of plant extracts used against cancer in traditional medicine. Sci Pharm. Jan-Mar 2010;78(1):33-45.

7. Alesaeidi S, Miraj S. A Systematic Review of Anti-malarial Properties, Immunosuppressive Properties, Anti-inflammatory Properties, and Anti-cancer Properties of Artemisia Annua. Electron Physician. Oct 2016;8(10):3150-3155.

8. Fox R. Anti-malarial drugs: possible mechanisms of action in autoimmune disease and prospects for drug development. Lupus. Jun 1996;5 Suppl 1:S4-10.

9. Mojab F. Antimalarial natural products: a review. Avicenna J Phytomed. Spring 2012;2(2):52-62.

10. Adedeji WA. The Treasure Called Antibiotics. Ann Ib Postgrad Med. Dec 2016;14(2):56-57.

11. Davies J, Davies D. Origins and evolution of antibiotic resistance. Microbiol Mol Biol Rev. Sep 2010;74(3):417-433.

12. Cheesman MJ, Ilanko A, Blonk B, Cock IE. Developing New Antimicrobial Therapies: Are Synergistic Combinations of Plant Extracts/Compounds with Conventional Antibiotics the Solution? Pharmacogn Rev. Jul-Dec 2017;11(22):57-72.

13. Elisha IL, Botha FS, McGaw LJ, Eloff JN. The antibacterial activity of extracts of nine plant species with good activity against Escherichia coli against five other bacteria and cytotoxicity of extracts. BMC Complement Altern Med. Feb 28 2017;17(1):133.

14. Gupta PD, Birdi TJ. Development of botanicals to combat antibiotic resistance. J Ayurveda Integr Med. Oct - Dec 2017;8(4):266-275.

15. Palombo EA. Traditional Medicinal Plant Extracts and Natural Products with Activity against Oral Bacteria: Potential Application in the Prevention and Treatment of Oral Diseases. Evid Based Complement Alternat Med. 2011;2011:680354.

16. Ravishankar B, Shukla VJ. Indian systems of medicine: a brief profile. Afr J Tradit Complement Altern Med. Feb 16 2007;4(3):319-337.

17. Saraswathy A, Rani MG, Alam MM. Development of high performance thin layer chromatography finger print parameters on maka vallati ilekiyam - part 1. Anc Sci Life. Jul 1999;19(1-2):11-16.

18. Cowan MM. Plant products as antimicrobial agents. Clin Microbiol Rev. Oct 1999;12(4):564-582.

19. Veeresham C. Natural products derived from plants as a source of drugs. J Adv Pharm Technol Res. Oct 2012;3(4):200-201.

20. Dias DA, Urban S, Roessner U. A historical overview of natural products in drug discovery. Metabolites. Apr 16 2012;2(2):303-336.

21. Kim HP, Son KH, Chang HW, Kang SS. Anti-inflammatory plant flavonoids and cellular action mechanisms. J Pharmacol Sci. Nov 2004;96(3):229-245.

22. Al-Abd NM, Mohamed Nor Z, Mansor M, Azhar F, Hasan MS, Kassim M. Antioxidant, antibacterial activity, and phytochemical characterization of Melaleuca cajuputi extract. BMC Complement Altern Med. Oct 24 2015;15:385.

23. Maddox CE, Laur LM, Tian L. Antibacterial activity of phenolic compounds against the phytopathogen Xylella fastidiosa. Curr Microbiol. Jan 2010;60(1):53-58.

24. Halabi MF, Sheikh BY. Anti-proliferative effect and phytochemical analysis of Cymbopogon citratus extract. Biomed Res Int. 2014;2014:906239.

25. Gunathilake K, Ranaweera K, Rupasinghe HPV. In Vitro Anti-Inflammatory Properties of Selected Green Leafy Vegetables. Biomedicines. Nov 19 2018;6(4).

26. Ashafa AO, Grierson DS, Afolayan AJ. In vitro antioxidant activity of extracts from the leaves of Felicia muricata thunb. An underutilized medicinal plant in the Eastern Cape Province, South Africa. Afr J Tradit Complement Altern Med. 2010;7(4):296-302. 